\title{
Aesthetic Study and Symbolic Meaning of Decoration in Traditional Wedding
}

\author{
Apsari Dj Hasan \\ Master of design, Postgraduate Faculty \\ Universitas Komputer Indonesia \\ Bandung, Indonesia \\ apsarihasan18@gmail.com
}

\begin{abstract}
- this study aims to obtain accurate data on the aesthetic values and symbolic meanings that exist in the bride's headdress on Gorontalo people's customary wedding attire. The method used was the qualitative-descriptive method that describes the various objects of the subject under study. The subject of the research is the aesthetic value and symbolic meaning of the bride's headdress on the traditional wedding dress of the Gorontalo community. The object of the research is the whole accessories in the bride's headdress on the traditional wedding dress of the Gorontalo community. The data collection is done through observation, interviews and documentation. Data are analyzed interactively, through data reduction stages, presenting data, drawing conclusions and verification. From the results of the research, it is known the meaning of the bride's headdress on the indigenous wedding of the Gorontalo community. Where the symbolic meaning is in every form of accessories in the headdress itself. This strongly illustrates the beliefs and traditional values that are still held firmly by the people of Gorontalo. Therefore, that it can be seen that every color and shape in the bride's headdress are a symbolic meaning that represents the attitude and responsibility of the bride.
\end{abstract}

Keywords-aesthetic value, shape, meaning of the bride's headdress

\section{INTRODUCTION}

One of the artworks in Gorontalo is traditional clothing. Gorontalo traditional clothing there are several types including traditional clothing for aqikah, traditional khitanan clothes, molondalo, and traditional wedding clothes. For traditional wedding clothes there are two types that are used in two processions, namely the marriage contract procession and the wedding reception procession. Custom wedding attire is one example of artwork that has been inherited from generation to generation so that it has become a local culture of the community. In marriage, the groom and the bride wear custom clothing and the groom is equipped with a head covering. Gorontalo brides are also famous for their luxurious, grand traditional clothing that contains the historical values of their ancestral heritage

The greatness of the Gorontalo area's traditional custom The greatness of the Gorontalo area's customary custom used by the bride when the reception or wedding party is called Bili'u. Gorontalo wedding dress is rich in various jewelry, which also shows the social status of the wearer. The bride's clothing consists of three parts, namely long-sleeved brackets or called Galenggo; an inner skirt dress called Buluwa Lo Rahasia or Oyilomuhu; and the outermost clothing that looks like a cloth full of golden ornaments called Alumbu or Bide.
On the chest is covered with Kububu Lo Duhelo, which is a chest decoration made of black velvet cloth with golden yellow ornaments. The bride's sleeves at the end of the day wore a Peetu ornament that was black in gold, and large bracelets looked majestic and luxurious. Details of the bride's hair and head jewelry look so complicated, magnificent, and unique. Headdresses like a queen's crown, with pink and white feather feathers. Uniquely, on the back of the head there is a decoration such as a 5-tiered long shield. In addition to clothing, Gorontalo brides also cannot be separated from various accessories that support their appearance. Not just any, each jewelry chooses its own rules and meanings to be used during the wedding day.

Reference [1] explained about the shape, function and meaning of male head covering on the traditional dress of the Gorontalo community. The results of the study only discussed the form, function and meaning of the male head cover on the Gorontalo community's custom wedding dress. Reference [2] explained the social solidarity of pluralism in the marriage tradition. This research was conducted to find out how the social slidarity of pluralism in the marriage tradition in one of the villages in Gorontalo by using organic solidarity theory. Reference [3] on the Process of Creation of Bridal Clothing Attributes with Tatah Technique, explained the aesthetic characteristics that exist in the bridal attributes of the Gorontalo community. This study focuses on discussing the process of creating bridal clothing attributes. The aim of this research is to find out the process of creating bridal dress attributes made of brass with a gown technique. The function of clothing is clothing for display, clothing for comfort, and clothing for modesty. The three aspects referred to by Morris were clothing for display, clothing for comfort, and clothing for politeness or appropriateness. Clothing as creative work is created with the aim of being functional and aesthetic. Artwork can be seen from the aesthetic aspect or from the meaning of the art object itself [4]. Beauty is the unity of form relationships that exist between the five senses [5].

Because there is no research discussing the bride's headdress on the traditional wedding of the Gorontalo community, the writer aims to examine the aesthetic value and symbolic meaning of the bride's headdress on the Gorontalo people's customary marriage. The purpose of this study was to find out in detail the aesthetic value of the bride's headdress according to the indigenous wedding culture of the Gorontalo community, as well as discuss the symbolic meaning of the entire headdress of the bride at the Gorontalo people's customary marriage. To support this research, qualitative 
research methods are used through descriptive analysis that describes events or events that are described as they are. The data needed is about Gorontalo culture, which is about the bride's headdress on the indigenous wedding of the Gorontalo community. The required data is collected by observation, literature study and documentation.

\section{METHOD}

\section{A. Research Methods}

The method used in the study is qualitative. The analysis used is descriptive analysis, which describes a phenomenon, event or event that is described as it is, used to solve and answer the problems that occur in the present. The data that has been collected is analyzed through data reduction, data presentation, and conclusion drawing. Analysis of the description in this study according to the foundation is used to find out the symbolic meaning of the bride's headdress on the indigenous wedding of the Gorontalo community. The questions posed are radical whose answers require extensive, complex and in-depth analysis.

\section{B. Analysis Process}

The research stage was carried out by collecting data on the object of research in the form of physical data and literature studies. The analysis process is carried out in three stages, namely determining the object of analysis, compiling the findings and interpretation data.

In the first stage is to determine the object of analysis. The overall physical data of the accessories used in the bride's headdress on the indigenous wedding of the Gorontalo community. Data in the form of pictures of each accessory used in the bride's headdress.

The next step is to compile findings data. Findings data are compiled after going through an assessment process of several research objects. Assessment of objects is carried out by including literature studies as a theoretical basis to support research. Literature study is carried out by collecting, reading, and reviewing data from literature sources related to research.

\section{RESULTS}

\section{A. Aesthetic value}

The ornamentation of the head of the bride is one of the objects of human creation in the people of Gorontalo who have beauty or aesthetic value. Every shape in the headdress is the aesthetic experience of the maker.

Each accessory consists of basic shapes such as rectangles and arches on a flat plane. The entire form in each accessory is able to make this bride's headdress look beautiful and luxurious.

\section{B. Color}

Color has meaning. Gorontalo traditional clothing generally has three colors and has a certain meaning, namely purple, golden yellow, and green. In addition to the Gorontalo traditional wedding ceremony, the community only uses four main colors, namely red, green, yellow gold and purple. Meanwhile, the white and blue colors of Gorontalo custom are the colors of grief or death; so it is not reserved for use in a series of wedding customs. Each of these colors is believed to

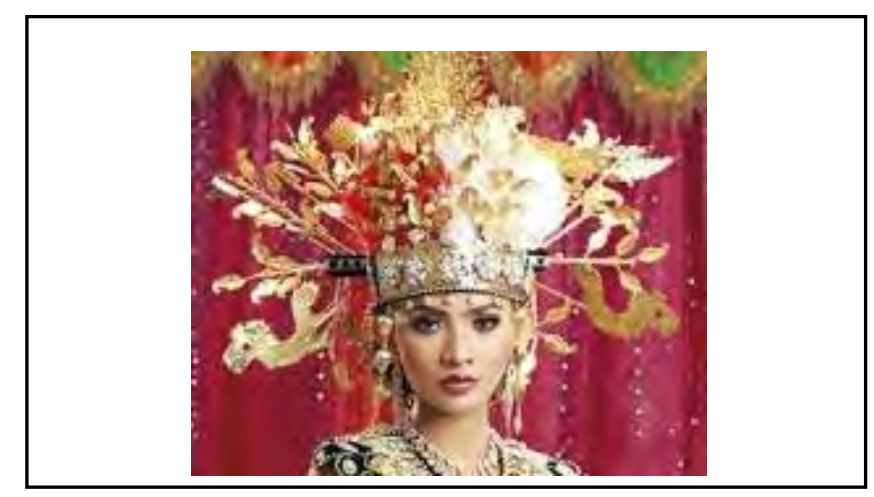

Fig 1. Headdress of the Bride in the Gorontalo Customary Wedding Dress.

Source:http://olamitarestorangorontalo.blogspot.c om/2017/09/busana-dan-aksesori-khaspengantin.html/ (2018)

have a certain meaning related to the values that grow and develop in the life of the Gorontalo people. But in the bride's headdress, the dominant colors are yellow gold and red. Gorontalo yellow color is believed by the people of Gorontalo to symbolize glory, loyalty, greatness and honesty and red color which symbolizes courage and responsibility. The female head ornament is shown in Figure 1.

\section{Shape and Meanings}

In addition to clothing, Gorontalo brides also cannot be separated from various accessories that support their appearance. Not just any, each jewelry chooses its own rules and meanings to be used during the wedding day. An object certainly has its own meaning such as meaning for the forms of accessories that are in the Gorontalo bride's headdress.

- Baya Lo bo'ute or a decoration similar to a headband tied to the head like Mahkota Ratu as shown in Figure 2. Has the meaning of the bride when thinking always with consideration, wisdom and responsibility. This headband also illustrates that the bride will soon be tied with a wedding rope and enter a new world with her rights and obligations as a wife.

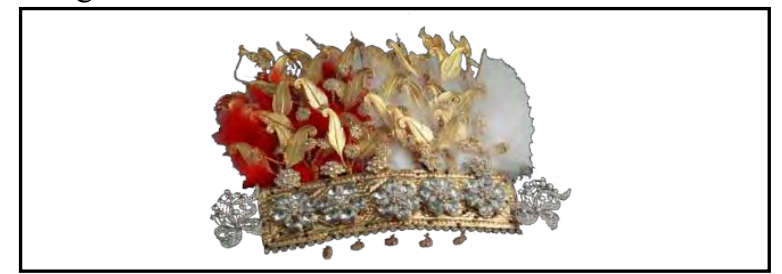

Fig 2. Baya Lo Bo'ute and Layi.

Source:http://olamitarestorangorontalo.blogspot. com/2017/09/busana-dan-aksesori-khas-

pengantin.html/ (2018)

- Layi / Lai-lai, namely red and white poultry feathers in figure 2. The feather is placed just above the crown of the front headband; the meaning is courage and chastity, and fine manners. 
- Paangge Moopa which is in the form of 6 short stems which likens 6 wise traditional stakeholders as shown in Figure 3.

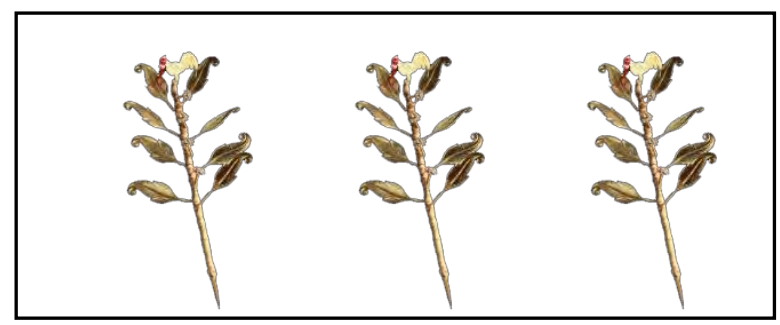

Figure 3. Paangge Moopa.

source:http://olamitarestorangorontalo.blogspot.co $\mathrm{m} / 2017 / 09$ /busana-dan-aksesori-khas-

pengantin.html/ (2018)

- $\quad$ Tutuhi / Tuhi, namely the number seven gafah in Figure 4 is a symbol of the seven great kingdoms that have mutual friendships in the Gorontalo tribe. These 7 kingdoms are between Gorontalo and Limboto, Gorontalo, Tuwawa, Bulonga, Limutu, and Atingola.

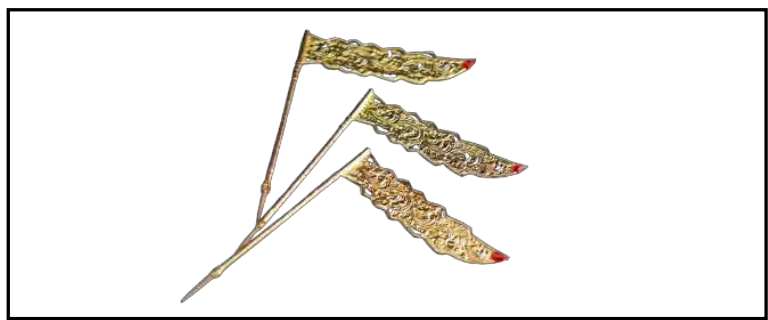

Figure 4. Tutuhi / Tuhi.

source:http://olamitarestorangorontalo.blogspot. com/2017/09/busana-dan-aksesori-khaspengantin.html/ (2018)

- Dungo-Bitila, which is a leaf or breadfruit leaf, which means shade. Can be seen in Figure 5.

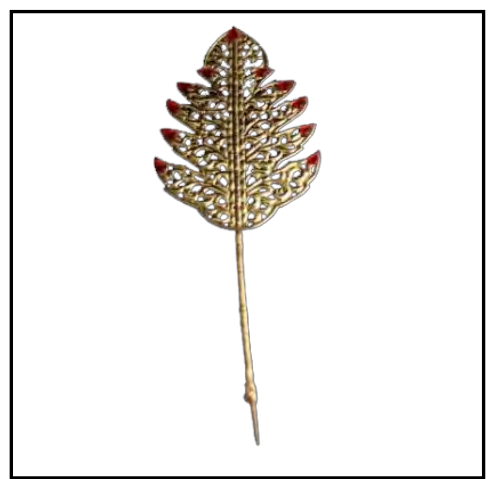

Figure 5. Duungo-Bitila.

source:http://olamitarestorangorontalo.blogspot. com/2017/09/busana-dan-aksesori-khas-

pengantin.html/ (2018)
- Taaya is usually called a scales, namely jewelry placed on the right and left of the upper forehead, shown in Figure 6 has the meaning of wisdom. Where the bride must be a wise wife.

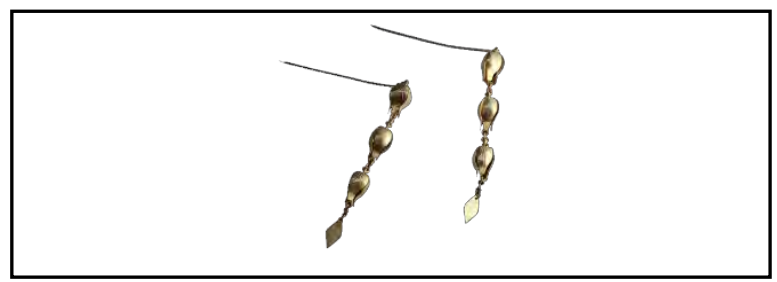

Figure 6. Taaya.

source:http://olamitarestorangorontalo.blogspot. com/2017/09/busana-dan-aksesori-khaspengantin.html/ (2018)

- Huli: shaped leaves or dragons that are pinned on the back of the right and left. Seen in Figure 7.

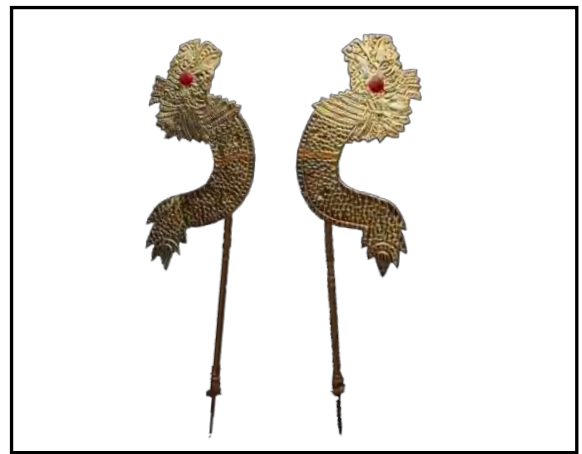

Figure 7. Huli.

source:http://olamitarestorangorontalo.blogspot. com/2017/09/busana-dan-aksesori-khaspengantin.html/ (2018)

- Huwo'o looks like a 5-layer shield extending down and shrinking as shown in Figure 8, meaning the recognition of God Almighty.

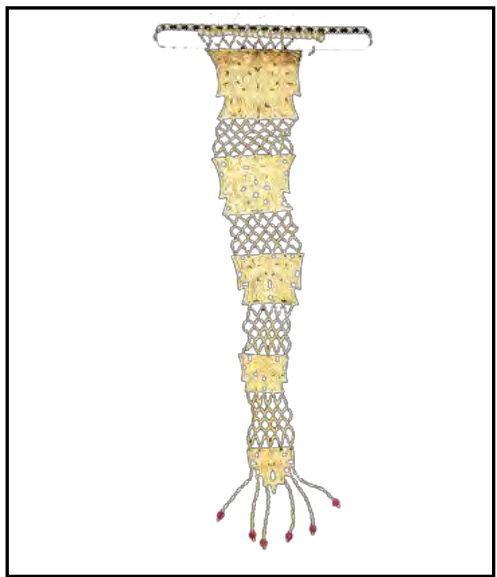

Figure 8. Huwo'o.

source:http://olamitarestorangorontalo.blogspot. com/2017/09/busana-dan-aksesori-khaspengantin.html/ (2018) 


\section{DISCUSSION}

Before carrying out the final analysis process, namely the interpretation of the findings data, first conduct a literature study conducted in this chapter. Literature study of the results of the data is divided into three parts as before, namely color, shape and meaning.

\section{A. Aesthetic Value}

Beauty in the sense of pure aesthetics, concerns the aesthetic experience of someone in relation to everything that is perceived. Whereas beauty in a limited sense, it is more narrowed so that it only concerns things that it perceives with vision, namely in the form of the invisible shapes and colors [6]. The description illustrates that in making the headdress and its accessories forms is an aesthetic experience for someone who makes it and the beauty found in the form of the headdress itself.

Another opinion said according to Kant, that: there are two kinds of aesthetic values, one of which is aesthetic value or pure value. Because the value is pure, then if there is beauty is said to be pure. This pure aesthetic value is found in lines, shapes, colors in fine art [7]. The shapes on the headdress have a pure aesthetic value on each accessory. Rectangular shape, curved on a flat plane and also on the decoration composition as accessories on the headdress

\section{B. Color}

In the bride's headdress there is a dominant base color as a characteristic of the traditional dress of the Gorontalo community. Reference [8] explained about color as one of the elements or medium of art, is a very important stacking element, both in the field of fine arts and applied arts. Even further than that color is very instrumental in all aspects of human life.

Based on the description above, it can be explained that every color on an object or an object that has something to do with human activity certainly has its own meaning. One of them is the color of the bride's headdress which has a meaning based on the traditions of the local community, especially in the research object of the bride.

\section{Shape and Meaning}

According to reference [9] meaning is meaning or purpose. Meaning is Linguistics or scientific study of language, meaning or purpose of a word [10]. In this case the meaning has its own understanding of each object. So that it can be said that meaning is interpreting something that is considered important. Researchers concluded that meaning is interpreting something that is considered important.

\section{CONCLUSION}

The headdress of the women bride is the overall beauty of the accessories. The meaning contained in the headdress is in the form of accessories, namely the shape of bitilla leaves or breadfruit leaves, the shape of the dragon and the shape of the shield. Every accessory has a meaning that can represent the responsibilities and attitudes of the bride. Besides that, the colors in each of the accessories have a symbolic meaning based on the belief of the people of Gorontalo, namely the golden yellow color which is a symbol of glory, loyalty, greatness and honesty, as well as the red color which symbolizes courage and responsibility.

\section{REFERENCES}

[1] Nurhayati, Dawali. Bentuk, Fungsi dan makna tudung Kepala Pria Pada Busana Adat Perkawinan masyarakat Gorontalo. Universitas negeri gorontalo, fakultas teknik, Jurusan pendidikan Teknik kriya (2013).

[2] Indra, Samaun. Solidaritas sosial Masyarakat Pluralisme Dalam Tradisi Perkawinan (Suatu Penelitian Pada Masyarakat Etnik Gorontalo dan tnik jawa di Desa Bandung Rejo Kecamatan Boliyohuto Kabupaten Gorontalo) (2015).

[3] Hariana. Proses Penciptaan Atribut Busana Pengantin Dengan Teknik Tatah. Universitas Negeri Gorontalo, Gorontalo Program Doktor Pengkajian Seni Pertunjukan dan Seni Rupa UGM (2017).

[4] Morris, D. People Watching : The Desmond Morris Guide to Body Language, London: Thames (2002).

[5] Read, H, The Meaning of Art, New York: Penguin Book (1959).

[6] Kartika, Dharsono Sony, dkk. Pengantar Estetika. Bandung: Rekayasa Sains (2004).

[7] Kartika, Dharsono Sony. Pengantar Estetika. Bandung: Rekayasa Sains (2007).

[8] Kartika, Dharsono Sony. Seni Rupa Modern. Bandung: Rekayasa Sains (2004).

[9] Hariana, Busana Adat Perkawinan Suku Gorontalo (Tesis). Bandung: Program Studi Desain Institut Teknologi Bandung (2008).

[10] Oxford Dictionary of English. Second Edition, Volume XVIII, Thro Unelucidated, Clarendon Press. Oxford (2003). 